Методика преподавания психологии / В. Я. Ляудис. - М. : Изд-во МГУ, 1984. - 82 с. 17. Павлова Л. Г. Спор, дискуссия, полемика / Л. Г. Павлова. - М. : Просвещение, 2001. - 127 с. 18. Пашукова Т. И. Методика ролевой дискуссии / Т. И. Пашукова. - Кировоград : Знание, $2008 . \quad-26$ с. 19. Психология общения и диалога учителя и учащихся / под ред. Г. В.Дьяконова. - Кировоград : Изд-во КГПИ, 1993. - 148 с. 20. Слободчиков В. И. Психология человека. Введение в психологию субъективности / В. И. Слободчиков, Е. И. Исаев. - М. : Школа-Пресс, 1995. - 384 с. 21. Флоренская Т. А. Диалог в практической психологии / Т. А. Флоренская. -М. : Изд-во НИИОПП, 2006. - 244 с. 22. Формирование учебной деятельности студентов / под ред. В. Я. Ляудис. - М. : Изд-во МГУ, 2006. - 240 с. 23. Хруцкий Е. А. Организация проведения деловых игр / Е. А. Хруцкий. - М. : Высшая школа, 2007. - 320 с.

УДК 378.011.3-051(477)

\author{
В. В. Желанова, \\ докторант, дочент, \\ Д3 «Луганський наиіональний \\ університет імені Тараса Шевченка»
}

\title{
ПРОВІДНІ НАПРЯМИ ТА ТЕНДЕНЦІї ДОСЛІДЖЕННЯ ПРОБЛЕМИ ПРОФЕСІЙНОӤ ПІДГОТОВКИ МАЙБУТНІХ УЧИТЕЛІВ ПОЧАТКОВИХ КЛАСІВ В УКРАЇНІ
}

У статті розкрито провідні напрями та тенденції дослідження проблеми фахової підготовки майбутнього вчителя початкових класів у ВНЗ на сучасному етапі, щуо збігається із запровадженням провідних ідей Болонської конвениії у систему вищої освіти в Україні.

Ключові слова: професійно значущі якості, готовність майбутнього вчителя до професійної діяльності, поліпарадигмальність, інтеграція наукових підходів, рефлексивна спрямованість, практична орієнтація освіти.

В статье раскрыты основные направления и тенденции исследования проблемы профессиональной подготовки будущего учителя начальных классов в вузе в современный период, который совпадает с внедрением ведущих идей Болонской конвенции в систему высшего образования в Украине.

Ключевые слова: профессионально значимые качества, готовность будущего учителя к профессиональной деятельности, полипарадигмальность, интеграчия научных подходов, рефлексивная направленность, практическая ориентация образования.

In the article basic directions and tendencies of research of problem of professional preparation of future teacher of initial classes are exposed in Institute of higher in a modern period which coincides with introduction of leading ideas of Bolonskoy convention in the system of higher education in Ukraine.

Key words: professionally meaningful qualities, readiness of future teacher to 
the of professional activity, polyparadyhmalnost, integration of scientific approaches, reflection orientation, practical orientation of education.

Підвищена увага до професійної підготовки майбутнього вчителя початкових класів у сучасному освітньому просторі в Україні $є$ цілком виправданою. Оскільки саме вчитель початкових класів стоїть у витоків формування особистості нової генерації - ініціативної, самостійної, креативної, з усвідомленим сприйняттям себе, розумінням своїх здібностей, фізичних сил, цілей і мотивів поведінки, свого ставлення до себе й інших людей, тобто «суб'єкта» свого життя. Відтак ключовим завданням сучасної підготовки фахівців даного напряму в умовах ВН3 $є$ формування особистості професіонала, здатного виконувати ці значущі завдання. Отже, сучасна педагогічна освіта змінює свій вектор з підготовки вчителя-фахівця, здатного лише на відтворення традиційної моделі педагогічної діяльності, на підготовку компетентного педагога-професіонала, який може будувати власну професійну діяльність, ціннісно-смисловою основою якої є особистість молодшого школяра. Досліджуючи проблему контекстного навчання майбутнього вчителя початкових класів, ми вважаємо, що саме в цій освітній системі відбувається перехід до особистісно-смислової парадигми освіти й створюються реальні умови для реалізації смислоутворювального контексту. На думку А. Вербицького, саме в межах контекстного навчання розв'язуються основні суперечності традиційного навчання у ВН3, які полягають у тому, що студент засвоює не саму культуру (наприклад, професії), а лише засіб iï засвоєння, отримує знання, відірвані від його майбутньої професії. Тобто постає питання доведення вагомості, доцільності й місця контекстного навчання в сучасній системі професійної підготовки майбутнього вчителя початкових класів у ВНЗ, що стає можливим за умови визначення провідних напрямів та тенденцій в дослідженні зазначеного феномену.

Метою статті є з'ясування провідних напрямів та тенденцій професійної підготовки майбутніх учителів початкових класів у ВНЗ на сучасному етапі, що збігаються із запровадженням провідних ідей Болонської конвенції в систему вищої освіти в Україні.

Проблему підготовки фахівців початкової освіти досить широко представлено в сучасній вітчизняній педагогічній теоpii. При цьому іiі нормативно-правовим підгрунтям $є$ такі спе- 
ціальні документи: Державна національна програма «Освіта» («Україна ХXI ст.», 1992 р.), закони України «Про освіту» (1996 р.), «Про загальну середню освіту» (1999 р.), «Про вищу освіту» (2002 р.), Концепція розвитку педагогічної освіти (1998 р.), Національна доктрина розвитку освіти в XXI столітті (2002 р.), Концептуальні засади розвитку педагогічної освіти України та іï інтеграції в європейський освітній простір (2004 р.) та ін. Після прийняття закону України «Про вищу освіту» почали розроблятися, а 32004 року впроваджуватися в практику Державні галузеві стандарти підготовки майбутніх фахівців $з$ початкової освіти (керівник робочої групи - директор Інституту педагогіки i психології НПУ імені М. Драгоманова В. Бондар). У цих документах, зокрема у законі України «Про освіту» (1996 р.), який є засадничим для нашої галузі, визначено нові правові орієнтири та методологіө розвитку освіти. При цьому метою освіти проголошено всебічний розвиток людини як особистості та найвищої цінності суспільства, розвиток ії талантів, розумових і фізичних здібностей, виховання високих моральних якостей, виховання громадян, здатних до свідомого суспільного вибору, саморозвитку та самовдосконалення. Отже, зміни, що відбулися в правовому полі національної освіти, передбачають проведення системних освітніх реформ й у сфері вищої освіти України. Модернізація цієї галузі освіти пов'язана 3 переглядом пріоритетів підготовки майбутніх фахівців, що потребує створення нової теоретикометодологічної бази професійно-педагогічної підготовки майбутнього вчителя початкових класів.

Методологічні, загальнопедагогічні основи розвитку професійної підготовки фахівців початкової освіти розглянуто в дослідженнях відомих вітчизняних науковців, а саме: гуманістичні засади підготовки вчителя початкових класів (В. Денисенко); реалізація особистісно зорієнтованої підготовки (О. Савченко); система психолого-педагогічної підготовки вчителя початкових класів (Л. Хомич); професійнонаукова підготовка (Б. Андрієвський); підготовка вчителя початкової школи в умовах запровадження Болонської конвенції, зокрема питання модульного навчання (В. Бондар), становлення багаторівневої освіти вчителів початкових класів (С. Власенко); професійна підготовка майбутніх учителів початкових класів в умовах навчального комплексу «педагогічний коледж - педагогічний університет» (О. Чепка); інваріантна компонента в підготовці вчи- 
теля початкових класів (О. Савченко); упровадження компетентнісного підходу (Н. Бібік, О. Савченко); технологічного підходу (Л. Коваль, І. Шапошнікова), зокрема інтерактивних технологій (О. Пометун), технологій моделювання педагогічних ситуацій (Л. Красюк), застосування мультимедійних засобів навчання (В. Імбер); питання підручникотворення (Я. Кодлюк).

Певний напрям складають дослідження, у яких обгрунтовано моделі підготовки вчителів початкових класів, а саме: концептуальна модель психолого-педагогічної підготовки вчителя початкових класів (Л. Хомич); теоретична модель інтегрованої підготовки майбутніх вихователів дошкільних закладів - вчителів початкових класів (М. Прокоф'єва); модель виховної діяльності (О. Отіч, О. Кіліченко); модель формування готовності студентів до національного виховання учнів початкових класів (С. Паршук); модель підготовки майбутніх учителів початкової школи до роботи з дітьми шестирічного віку (О. Савченко).

Вагомим доробком є дослідження певних напрямів підготовки, пов'язаних 3 реалізацією провідних аспектів професійної діяльності майбутнього вчителя початкових класів, а саме: підготовка до гуманізації педагогічного процесу (А. Крамаренко); соціально-педагогічної діяльності (С. Літвиненко); діагностичної роботи (С. Мартиненко, О. Мельник); професійної діяльності в умовах інклюзивної освіти (I. Демченко); впровадження дидактичних технологій у початковій школі (О. Мірошниченко), зокрема використання інтерактивних технологій (Н. Павленко); організації групової навчальної діяльності (C. Ратовська); розв'язання дидактико-методичних задач (О. Маляренко); варіативної організації навчально-пізнавальної діяльності учнів на уроках математики (М. Овчинникова); використання комп'ютера як універсального дидактичного засобу навчання (О. Шиман); формування професійних інтересів учнів (Л. Тимчук); історико-краєзнавчої роботи (О. Пірожкова, С. Танана); формування естетичного досвіду молодших школярів (Н. Пахальчук); позакласної музично-виховної діяльності (Б. Нестерович); валеологічного виховання учнів (О. Філіпп'єва); фізичного виховання учнів (А. Степанко); організації спортивно-масової роботи (Б. Максимчук); художньо-технічної творчості учнів (Н. Колеснік); педагогічного керівництва самостійною роботою учнів (М. Парфьонов); 
роботи з активізації самостійної пізнавальної діяльності молодших школярів (Є. Улятовська); роботи 3 батьками (Т. Шанскова); національного виховання учнів (С. Паршук, С. Лавриненко); правового виховання молодших школярів (Л. Мацук); формування комунікативних умінь учнів в умовах відкритої соціально-педагогічної системи (Н. Котух); організації спілкування учнів у процесі розвиваючих ігор (Л. Філатова); класного керівництва (О. Шквир); позаурочної виховної роботи (І. Казанджи); попереджувально-корекційної роботи з учнями (О. Баранова).

Низку досліджень присвячено аналізу проблем щодо формування готовності майбутнього вчителя до різних аспектів професійної діяльності, а саме: особистісно зорієнтованого навчання (Ю. Шаповал); гуманістичного виховання учнів (Д. Пащенко); проведення педагогічних досліджень (Л. Коржова); складання та розв'язання навчальнопізнавальних завдань (Т. Бєльчева); застосування інтерактивних технологій навчання (Л. Бекірова); використання персонального комп'ютера як засобу навчальної діяльності (Р. Моцик); створення виховних ситуацій (О. Демченко); розвитку креативності молодших школярів (В. Фадєєв); професійного саморозвитку (А. Бистрюкова).

Вагомими є дослідження, у яких обгрунтовано необхідність формування системи професійно значущих якостей майбутнього вчителя початкових класів у період навчання у ВН3 (М. Федоренко), або певних із них, а саме: гуманістичної спрямованості (А. Кудусова), ціннісних орієнтацій (В. Денисенко), професійно-педагогічних цінностей (С. Єрмакова), системи знань про інформаційні технології (С. Гунько), творчих здібностей (В. Чорноус), творчої особистості (Н. Кічук), здатності до рефлексії (Т. Яблонська), комплексних педагогічних (О. Острянська), професійних (Ж. Сироткіна) умінь, умінь використовувати засоби інформаційних технологій (О. Снігур), художньо-графічних умінь i навичок (О. Саган), навичок професійного спілкування на уроках музики (І. Кучерак), аксіологічної компоненти педагогічної культури (В. Паскар); комунікативної культури (В. Садова), естетичної культури (Л. Гарбузенко), інформаційної культури (А. Коломієць), національної художньої культури (Т. Мітяшкіна), культури міжнаціонального спілкування (Т. Атрощенко), ключових компетентностей особистості фахівця (Н. Кичук), зокрема, етичних компетентностей 
(Л. Хоружа), інформативних компетентностей (Л. Пєтухова), інформаційних компетентностей (О. Нікулочкіна), стилю педагогічного спілкування (М. Кулеша), екологічної свідомості (М. Хроленко), професійного самовизначення (О. Кисла), професійного самовдосконалення (Л. Сущенко), професійного самовиховання (О. Кучерявий).

Значущими є історіографічні дослідження процесу становлення та розвитку професійної підготовки майбутніх учителів початкової школи у ВНЗ України (К. Авраменко, Л. Коваль), оскільки професійна підготовка майбутніх учителів початкової школи в системі вищої школи розпочалася з 1956 року й осмислити та об'єктивно оцінити іï сучасний стан та потреби, як доводить відомий історик педагогіки О. Сухомлинська, можна лише в контексті історичного виміру іï розвитку. «Нині неможливо розпочати розв'язання проблеми, не визначивши, що ж було зроблено до цього, від чого потрібно відштовхнутисә, розвиваючи, розбудовуючи нове знання» $[4$, с. 8$]$. Відтак ретроспективний аналіз теорії та практики професійної підготовки студентів $є$ важливим джерелом грунтовного розуміння сучасних проблем педагогічної освіти.

Отже, аналітичний розгляд зазначених праць дозволив виокремити певні напрями щодо дослідження проблеми підготовки майбутнього вчителя початкових класів у ВН3, а саме: історіографічні дослідження процесу становлення та розвитку професійної підготовки майбутніх учителів початкової школи у ВН3; обгрунтування теоретико-методологічних й загальнопедагогічних засад фахової підготовки майбутнього вчителя початкових класів; дослідження певних напрямів підготовки, відповідних провідним аспектам професійної діяльності майбутнього фахівця початкової освіти; обгрунтування моделей підготовки вчителів початкових класів; аналіз проблеми формування різних напрямів готовності майбутнього вчителя до професійної діяльності; дослідження процесу формування професійно значущих якостей майбутнього вчителя початкових класів у період навчання у ВНЗ.

Другим аспектом розкриття заявленої теми стало визначення провідних тенденцій дослідження фахової підготовки майбутнього вчителя початкових класів у ВНЗ. Під тенденціями (від лат. tendo - направляю, прагну) ми розуміємо можливість тих чи інших дій розвиватися в певному напрямку, тобто, це поняття містить широкий спектр умов, критеріїв, принципів й інших явищ, виникнення, зміна, вияв або зник- 
нення яких помітно впливає на розвиток вищої освіти. Розглянемо їх.

У сучасному освітньому просторі в Україні відбувається становлення нової парадигми. Складність і суперечливість цього процесу полягає в тому, що в сучасній вищій освіті існує як мінімум дві парадигми, а саме: когнітивна, знаннєва, тобто традиційна, та гуманістична, або особистісно зорієнтована (Г. Балл, І. Бех, А. Бойко, Н. Гавриш, І. Зязюн, О. Савченко й ін.). Поліпарадигмальність сучасної освіти передбачає співіснування кількох методологічних систем, у межах яких створюються цілісні, закінчені моделі освітнього процесу, виражені у формі педагогічних теорій, технологій, систем навчання і виховання. Інтегрувати універсум когнітивної та особистісної освітніх парадигм можливо саме в межах рефлексивно орієнтованої парадигми, оскільки саме вона буде сприяти подоланню протиріч, пов'язаних зі становленням нової освітньої парадигми (В. Желанова, А. Лозенко, Н. Павленко). Відтак поліпарадигмальний характер освіти ми розглядаємо як методологічний принцип та вагому тенденцію сучасного процесу фахової підготовки майбутнього вчителя початкових класів.

Методологічною основою сучасних досліджень проблеми підготовки фахівців початкової освіти є також інтеграція певних наукових підходів.

Аксіологічний підхід, що спрямований на формування ціннісно-смислової сфери особистості майбутнього фахівця. Так, у докторському дослідженні Д. Пащенка розроблено концепцію та методику гуманізації професійної підготовки майбутніх учителів початкових класів на основі формування загальнолюдських цінностей (співчуття, гуманності, милосердя) [3].

Компетентнісний підхід, що реалізується у двох аспектах: як результативна складова освітнього процесу, тобто набуття студентами певних компетентностей, та як готовність формувати в учнів ключові та предметні компетентності (Н. Бібік, Л. Коваль, О. Савченко, Н. Черв'якова, І. Шапошнікова). Отже, специфіка компетентнісного навчання майбутнього вчителя початкових класів полягає в тому, що воно спрямоване не на засвоєння готових знань, які пропонуються кимось, а на дослідження умов виникнення цього знання.

Системний підхід, цінність якого полягає в тому, що він дозволяє вивчати певні явища в цілісності та структурованості. У докторському дослідженні Л. Хомич обгрунтована система 
психолого-педагогічної підготовки вчителя початкових класів, що передбачає формування системних знань про людину як суб'єкта освітнього процесу, який поєднує навчання, виховання та розвиток. Дослідниця підходить до розроблення змісту психолого-педагогічної підготовки фахівців як комплексної програми, підгрунтям якої $є$ програмно-цільовий метод планування й управління процесом навчання, спрямований на гуманізацію та демократизацію вищої школи, розвиток у студентів багатогранності та гнучкості мислення, формування педагога-дослідника, здатного розвивати особистість молодшого школяра [5, с. 127] .
Діяльнісний
підхід
(Г. Атанов,
С. Ратовська, С. Літвиненко). Праксіологічні аспекти професійної підготовки майбутніх вчителів початкових класів пов'язані з діяльнісною теорією засвоєння соціального досвіду, що розроблена в працях Л. Виготського, О. Леонтьєва, П. Гальперіна, В. Давидова та ін. Відповідно до неї засвоєння змісту навчання здійснюється не шляхом прямої передачі студенту інформації, а в процесі його власної, внутрішньо мотивованої активності, спрямованої на предмети та явища навколишнього світу. За допомогою активної, «пристрасної» (О. Леонтьєв) діяльності здійснюється привласнення людиною соціального досвіду, розвиток його психічних функцій і здібностей, систем стосунків з об' єктивним світом, іншими людьми і самим собою.

Технологічний підхід (О. Комар, О. Свдокимов, І. Манькусь, Н. Побірченко, І. Смолюк). У дослідженні Л. Коваль доведено, що зміни в змісті та методах навчання студентів, пов'язані з реалізацією технологічного підходу, дозволяють майбутнім учителям засвоювати знання про сутність загально навчальних технологій; оволодівати загальним алгоритмом їх застосування з урахуванням специфіки кожної; проводити та аналізувати уроки за різними загально навчальними технологіями; виявляти бажання організовувати технологічний процес навчання в початкові школі [2, с. 84].

Диференційований підхід. У докторській дисертації П. Гусака, присвяченій диференційованому навчанню майбутніх учителів початкових класів, цей підхід тлумачиться як принцип, концепція та технологія. Зокрема технологія диференційованого навчання розкривається автором як організація навчального процесу, що забезпечує формування власного стилю діяльності студентів на основі врахування їхніх ін- 
дивідуально-типологічних особливостей. Диференційоване навчання передбачає різноманітне групування майбутніх фахівців з метою вироблення відповідних оптимальних способів засвоєння навчального матеріалу [1].

Суб'єктний підхід (Г. Балл, Н. Гавриш, В. Желанова, С. Максименко, В. Роменець, В. Татенко, М. Федоренко, В. Ямницький). На думку зазначених науковців, професійна суб'єктність вчителя початкових класів є вагомою професійно значущою якістю. Ми розуміємо ії як інтегровану якість особистості, що забезпечує цілеспрямовану й оптимальну реалізацію своїх психічних, особистісних ресурсів для розв'язання професійних та життєвих завдань, що виявляється в прагненні до самовизначення, самодетермінації, саморегуляції та самовдосконалення у професійній діяльності.

Середовищний підхід (Л. Панченко, А. Петухова, Р. Пріма, О. Фаст). Упровадження цього підходу в сучасну освітню систему ВН3 дозволяє організувати навчальний процес на засадах реалізації суб'єктності особистості й таких їі провідних механізмів, як самовизначення та самореалізація. Отже, середовищний підхід зміщує акценти із взаємодії педагога та студента на його взаємодію з освітнім середовищем. Запропонований у нашому дослідженні феномен рефлексивноконтекстного освітнього середовища забезпечує осмислення суб' єктами освітнього процесу, самих себе в ньому, своїх партнерів, стосунки з ними, характер взаємодії, уявне проектування ресурсного забезпечення, а також технологічний складник процесу освіти. У такому середовищі засобами впровадження різних видів професійного контексту відбувається трансформація навчальної діяльності в професійну й рефлексивну як вагомого іiї складника.

Відтак методологічний концепт сучасних досліджень щодо проблематики фахової підготовки майбутнього вчителя початкових класів відбиває інтеграцію низки наукових підходів.

Вагомою тенденцією сучасної освіти в Україні є іï рефлексивна орієнтація (І. Бех, Н. Бібік, Г. Дегтяр, Н. Ничкало, Т. Яблонська). Оскільки змінюються іiі базові орієнтири - від «освіти на все життя» - до «освіти через все життя», самоосвіти. Тобто метою сучасної вищої школи є підготовка фахівця, здатного працювати не на рівні дій та операцій, коли мета відома й не підлягає рефлексії, а на рівні діяльності, коли мета зумовлюється смислом, і в людини є альтернатива вибору, що потребує рефлек- 
ciї, яка $є$ значущою саме для педагогічної діяльності в силу іiі дослідницького, нерегламентованого характеру. Отже, дійсно, процес гуманізації, що пронизує діяльність сучасної вищої школи, вимагає підвищеної рефлексії в пізнанні людиною самої себе і підвищеного відчуття відповідальності за іншу людину.

Аналіз сучасного етапу розвитку професійної підготовки майбутніх учителів початкової школи дозволяе стверджувати, що іiї вдосконалення пов'язане з упровадженням практико-орієнтованих систем навчання, які дозволяють організувати навчальний процес у ВНЗ з урахуванням специфіки майбутньої професії. Це сприяє розв'язанню проблеми переходу від навчання до праці. Найбільш продуктивною в цьому плані $є$ технологія контекстного навчання. Оскільки, на думку іiі засновника А. Вербицького, саме в межах контекстного навчання відбувається трансформація навчальної діяльності в професійну, тобто знання $з$ предмета навчальної діяльності перетворюються в засіб регуляції професійної діяльності. Отже, вагомість і значущість проблеми впровадження системи контекстного навчання в процес професійної підготовки фахівців є очевидною. Система контекстного навчання починає поширюватися й в Україні (В. Желанова, І. Марчук, О. Ткаченко).

У статті ми не мали можливості розглянути всі аспекти щодо напрямів та тенденцій дослідження проблеми підготовки майбутнього вчителя початкових класів, а зупинилися лише на певних. Отже, ми виокремили такі напрями дослідження зазначеної проблеми, як: історіографічні аспекти; теоретикометодологічні засади; певні напрями підготовки, відповідні провідним складником професійної діяльності; моделі підготовки; формування різних напрямів готовності до професійної діяльності; дослідження процесу формування професійно значущих якостей майбутнього вчителя початкових класів у період навчання у ВНЗ. Найбільш вагомими тенденціями дослідження проблеми підготовки майбутнього вчителя початкових класів $є$ iї поліпарадигмальність, інтеграція аксіологічного, компетентнісного, системного, діяльнісного, технологічного, диференційованого, суб' єктного, середовищного наукових підходів як іï методологічної основи, рефлексивна спрямованість, поширення практико-орієнтованих систем навчання. Подальшого розгляду потребує питання щодо впровадження задачного підходу, а також тенденції до психологізації та інформатизації процесу фахової підготовки майбутніх учи- 
телів початкових класів у ВНЗ.

\section{Література}

1. Гусак П. М. Теорія і технологія диференційованого навчання майбутніх учителів початкових класів : дис. ... доктора пед. наук : спец. 13.00.01 / П. М. Гусак. - Луцьк, 1999. - 432 с. 2. Коваль Л. Професійна підготовка майбутніх учителів у контексті розвитку початкової освіти : [монографія] / Л. В. Коваль. - Донецьк : ЛАНДОН-ХХІ, 2012. - 343 с. 3. Пащенко Д. І. Формування готовності майбутніх учителів початкових класів до гуманістичного виховання учнів : [монографія] / Д. І. Пащенко. - К. : Науковий світ, 2005. 370 с. 4. Сухомлинська О. В. Історико-педагогічний процес : нові підходи до загальних проблем / О. В. Сухомлинська. - К. : АПН., 2003. - 68 с. 5. Хомич Л. О. Система психолого-педагогічної підготовки вчителя початкових класів : дис. ... доктора пед. наук : спец. 13.00.04 / Л. І. Хомич. - К., 1999. - 408 с.

УДК 130.123.1:130.2

Н. М. Костриця, кандидат пед. наук, доцент, Національний університет біоресурсів та природокористування Украӥни

\section{ВИКОРИСТАННЯ ІДЕЙ СИНЕРГЕТИЧНОГО ПІДХОДУ В КУЛЬТУРОЛОГІЧНІЙ ОСВІТІ}

Використання ідей синергетичного підходу в освіті пов'язано з відтворенням досвіду, накопиченого в культурі та створенням належних умов для його иілеспрямованої зміни.

Ключові слова: синергетика, синергетичний підхід, система, освітня система, система культурологічної підготовки.

Использование идей синергетического подхода в образовании связано с воспроизведением опыта, накопленного в культуре и созданием надлежащчих условий для его иелеустремленного изменения.

Ключевыеі слова: синергетика, синергетический поход, система, образовательная система, система культурологической підготовки.

Using synergetic approach in education is related to the reproduction of the cultural experience.

Key words: synergy, synergetic approach, system, educational system, modernization, the system of cultural training.

Нині розуміння пріоритетності культури стосовно технології в процесі розвитку цивілізації нині стає системним. Дедалі більше науковців і практиків у сучасному світі усвідомлюють, що будь-які спроби розв'язати глобальні екологічні 